\title{
MAPPING MUTATIONS IN LEGISLATION: A BIOINFORMATICS APPROACH
}

Parliamentary Affairs, 2018, forthcoming.

Ruth M. Dixon and Jonathan A. Jones

\begin{abstract}
Affiliations
Ruth M. Dixon: Blavatnik School of Government, University of Oxford, Oxford, UK. Jonathan A. Jones: Department of Physics, University of Oxford, Oxford, UK.
\end{abstract}

\begin{abstract}
Legislative amendment poses a conundrum: why do governments amend legislation that they only recently drafted? An effective method for quantifying amendments across a wide range of policy areas and legislatures would be valuable for answering such questions. Existing studies almost all rely on hand-counting and coding of amendments, methods which are laborious, necessarily subjective, and difficult to replicate. Using insights from bioinformatics (the study of genetic codes), we developed a streamlined method to quantify and visualize the amount of amendment. In an exploratory study of three parliamentary sessions since 2008, we found that UK legislation was considerably amended and lengthened during the parliamentary process. We discuss our results in the light of theories of information asymmetries between the government and the legislature.
\end{abstract}

Keywords:

Amendment analysis; Data visualization; Legislative process; Parliamentary scrutiny; Westminster

\section{Acknowledgements}

We thank several former and current parliamentary officials and civil servants for generously and patiently answering our questions about the parliamentary process. We are also very grateful for comments from colleagues and reviewers. No funding was received for this study. 


\section{Introduction}

There is increasing academic interest in the legislative process across a range of jurisdictions (e.g. Kreppel 1999; Tsebelis et al. 2001; Shephard and Cairney 2005; Martin and Vanberg 2011; Thompson 2015; Pedrazzani and Zucchini 2013; Russell and Gover 2017). Specifically, the amendment of legislation throws light on the parliamentary process. In this paper, we explore the question, why is legislation amended? While scrutiny and amendment of bills is one of the primary functions of legislatures, there are several reasons why it might be expected that government legislation should rarely be amended. First, in most parliamentary systems, government legislation is introduced to the legislature only after an extended process of consultation and pre-legislative scrutiny, which should ensure that the policy intent of the legislation is clear. Second, legislative drafting is carried out by expert professionals, which should ensure that the policy intent is faithfully reproduced in the legislative language. Third, while opposition or backbench legislators are very likely to signal their opposition to the bill by proposing amendments, by virtue of its majority a government can normally resist such 'non-government' amendments while ensuring the success of its own. These reasons would lead us to predict that (a) 'government' amendments (those proposed in the name of the minister sponsoring the bill) should rarely be proposed but almost invariably agreed, and (b) 'non-government' amendments should frequently be proposed but rarely agreed. Overall, legislative amendments should be very rare.

The relatively few empirical studies on this topic show that these expectations are not wholly met. All available evidence from a range of legislatures suggests that amendments are in fact very common (see e.g. Griffith 1974; Drewry and Brock 1993; Shephard and Cairney 2005; Martin and Vanberg 2011; Pedrazzani and Zucchini 2013; Thompson 2015; Russell and Gover 2017). Nevertheless, some legislative behaviour is in accordance with expectations. For example, almost all government amendments are agreed. Russell and Gover (2017: 70) showed that this applied to almost 95 per cent of government amendments in 12 UK bills from 2005 to 2012. Thompson (2015:54) showed that the 'success rate' for government amendments in House of Commons public bill committees from 2000 to 2010 was even higher, at 99.9 per cent. Similar success rates for government amendments were found by other authors (e.g. Griffith 1974:209; Drewry and Brock 1989:81; Shephard and Cairney 2005).

These and other studies also show that, as expected, large numbers of non-government amendments are proposed but not agreed. For example, in the study cited above, Russell and Gover (2017:70) found that an average of almost 300 non-government amendments were proposed per bill, but only 3.6 per cent were agreed. Thompson (2015:58) found that non-government amendments in bill committees were far more numerous than government amendments but enjoyed a success rate of only 0.6 per cent. Shephard and 
Cairney (2005) found that 87.6 per cent of non-executive amendments were unsuccessful in 50 executive bills passed by the Scottish Parliament in 1999-2003.

Contrary to expectations, however, government amendments are in fact surprisingly common. For example, in a study of 29 UK government bills on Heath and Criminal Justice topics between 1973 and 2010, Hood and Dixon (2015) found that an average of 400 government amendments per bill were agreed (while agreed non-government amendments averaged about 15 per bill). Similarly, Thompson (2015) found that 88 per cent of government bills were amended in the House of Commons committee stage from 2000 to 2012, averaging over 50 government amendments per bill from just that parliamentary stage (calculated from Thompson 2015:52,54). Russell and Gover (2017:76) found that on average more than 60 government amendments were agreed per bill in their sample of 12 UK government bills. In their study of bills in the Scottish Executive, Shephard and Cairney (2005) found that an average of over 100 ministerial amendments were agreed.

These results pose a theoretical puzzle. Why do governments so frequently amend legislation that they have only just drafted? One possible reason is that governments are not entirely 'rational actors.' The minister sponsoring the bill has an informational advantage over other legislators both in her own and opposing parties, by virtue of her knowledge both of the policy area and the preferences of other legislative actors (Martin and Vanberg 2011:10; Pedrazzani and Zucchini 2013). She can use that advantage to draft legislation that is both consistent with her own party's policy, and anticipates and forestalls objections that might arise during the legislative process. If that advantage was complete, the bill should pass without amendment. Amendments, therefore, are evidence of 'bounded rationality' on the part of the governmental sponsor of the bill, that is, incomplete knowledge of the current or future situation (Simon 1957; Krehbiel 1991).

When the minister's knowledge is incomplete, unforeseen objections can arise which force amendments to the bill. Supporting this thesis of bounded rationality, Pedrazzani and Zucchini (2013) found that in the Italian legislature, government bills that dealt with complex subjects and multiple policy dimensions were subject to more amendment. As we have seen, however, amendments rarely take the form of agreed non-government amendments. Instead, the studies cited above show that governments can usually avoid non-government amendments. However, those studies also found that a substantial proportion of government amendments had their origins in non-government proposals. Thompson found that over 9 per cent of agreed (government) amendments originated in non-government proposals (Thompson 2016:43). And through an innovative 'legislative strands' approach, Russell and Gover showed that non-government legislators frequently influenced the amendments eventually incorporated into legislation (Russell and Gover 
2017). Political factors are also important, of course, and failing to predict the strength of opposition to a bill will also be expected to lead to more amendment. Martin and Vanberg found that across five European legislatures, legislation on issues that divided coalitions were more amended than less contentious legislation (Martin and Vanberg 2011, 2014); a finding replicated in the study of Italian legislation (Pedrazzani and Zucchini 2013).

Alongside these issues of bounded rationality, we should consider the relative strengths of the executive and the legislature. We might expect that amendments would be fewer in the case of a 'weak' legislature, where the executive can resist calls for concessions. On the other hand, a strong executive might more easily 'change its mind' and impose amendments on a weak legislature without fear of opposition. However, there have been very few comparative studies that address this question. In their unique study of over 1300 legislative proposals from five European countries, Martin and Vanberg found no significant or substantive difference in the amount of amendment made by three 'strong' and two 'weak' European legislatures (Martin and Vanberg 2011:79). Of course, even an institutionally weak legislature may be in a position to exert more influence if the government has a small majority, a question that can be tested empirically within one country.

In order to address this type of empirical question, we require a widely applicable method to measure the degree of legislative change. Almost all of the studies cited above relied on hand-counting and coding of amendments, an arduous and time-consuming task. Such studies tended to analyse relatively small numbers of bills in detail, or concentrated on particular legislative stages. Nevertheless most of these studies involved counting and classifying thousands or tens of thousands of amendments, making them extremely dependent on researcher time and expertise and difficult to replicate or extend. To address this methodological gap, we developed a novel method to quantify and visualise the degree of legislative change. We demonstrate this method through an exploratory analysis of three UK parliamentary sessions.

\subsection{The UK legislative process}

Before describing our empirical study we set the scene by outlining the UK legislative process. In the UK, about thirty major pieces of primary government legislation are produced each year. A government bill is prepared by the sponsoring department on the orders of the government minister. A team of civil servants (the 'bill team') defines the scope and policy intent of the legislation (Page 2003). Departmental lawyers translate the policy intent into instructions for the specialist drafters, known as Parliamentary Counsel (Page 2009). Formal and informal mechanisms are provided for consultation and prelegislative scrutiny. Some bills are preceded by the publication of Green and White papers inviting consultation. Several parliamentary committees scrutinise draft bills, for example 
the Joint Committee on Human Rights considers the compatibility of every government bill with national and international human rights obligations (Tolley 2009). Some draft bills enter formal pre-legislative scrutiny by the relevant select committee, which is normally that of the department sponsoring the bill, but occasionally an ad hoc cross-departmental and/or cross-chamber committee (Constitution Committee 2004, Smookler 2006). The entire process is designed to produce high quality legislation requiring few or no government amendments (Cabinet Office 2017: 172). Russell and Gover (2017:74) quote a government insider saying that 'we are very often told that the bill must be in a state where no government amendments will be needed' - while acknowledging the near-impossibility of that aim.

Following the consultation process and any consequent redrafting, the bill enters one of the parliamentary chambers: the House of Commons or the House of Lords. About two-thirds of bills first enter the (elected) House of Commons, the remainder enter the (unelected) House of Lords. The bill passes through five parliamentary stages in the first chamber (first reading, second reading, committee, report, and third reading stages) before returning to the other chamber to go through the same stages. A plenary vote is taken after the second reading of a bill which settles its general principles (Cabinet Office 2017:218). Amendments can be made in the House of Commons committee and report stages, and in the House of Lords committee, report and third reading stages. Indeed, once the bill has received its second reading, changes to the bill can only be made via amendments. After passing through both chambers, the bill is returned to its original chamber for consideration of any amendments made in the second chamber, and may be shuttled several times between chambers until the final wording is agreed (a process known as 'ping-pong').

Some details of the process differ between the chambers. The Lords committee stage allows all peers to take part (whether in the Lords chamber or in a Grand Committee), while the Commons committee stage is generally handled by a Public Bill Committee comprising about 20 MPs reflecting the party proportions in the Commons, and much more rarely by a Committee of the Whole House (Levy 2010). Reflecting the primacy of the House of Commons, legislation concerning taxation and government expenditure is not normally amended by the Lords (Constitution Committee 2011). The three largest groups in the Lords are Conservative, Labour, and cross-bench peers (peers with no formal party affiliation) in approximately equal numbers (Russell and Gover 2017: 15), and thus the government can be sure of passing (or resisting) amendments in the Commons but not in the Lords, which is reflected in the fact that far more 'non-government' amendments are agreed in the Lords than in the Commons (Russell and Gover 2017: 71). As the unelected second chamber, the House of Lords does not have the power to insist that an amendment is not overturned by the Commons but nevertheless often uses its influence to put an issue on the agenda for the Commons to re-deliberate (Russell and Gover 2017: 279). 
The UK parliament ('Westminster') is often portrayed as an example of a 'weak' legislature, rarely influencing the substance of legislation prepared by the executive (e.g. Norton 1993, Gallagher et al. 2011). Westminster is regarded as being at the opposite end of the spectrum to the 'transformative' US congress (Mezey 1979), and weaker than other western European parliaments (Martin and Vanberg 2011). Such assertions are based on, for example, Westminster's strong party discipline, the rarity of coalition governments, and the ad hoc nature of legislative scrutiny committees, factors that are assumed to strengthen the executive relative to the legislature. When these assumptions are looked into more closely, however, a more nuanced picture emerges (Flinders and Kelso 2011; Russell and Cowley 2015; Russell et al. 2016). As we have seen above the influence of the legislature cannot simply be assessed by counting non-government amendments, as a substantial proportion of government amendments are made as concessions to non-governmental arguments.

\subsection{Empirical study}

Which brings us to our central questions: how and why do governments amend bills? The descriptions above of both the institutional system and our theoretical understanding of the legislative process lead us to the following predictions that we can test empirically.

First, we predict that the degree of amendment will vary across parliamentary stages, reflecting the different conventions and rules that apply to each stage. For example, Cabinet Office guidelines say that 'where possible, government amendments should be tabled at Committee rather than Report Stage.' (Cabinet Office 2017). And, in the Lords, issues already debated and decided cannot be reopened at the Lords Third Reading stage (House of Lords 2011). Amendments made at that stage are generally intended to tidy up the bill, or for ministers to fulfil commitments made at earlier stages in the process.

Hypothesis 1a: Committee stages will amend bills more than Report Stages

Hypothesis $1 b$ : Lords Third Reading stage will have the least amendment.

Second, we applied the method to understand the overall amount of amendment. As described above, we argue that 'boundedly rational' governments need to amend legislation as they cannot wholly predict problems with and objections to a bill. Further, we expect that where a government is 'weaker' its legislation will be more amended in order to enable the bill to pass. Our sample of sessions includes both a coalition and two single-party majority governments. To assess the 'strength' of each government, we included both its parliamentary majority and its coalition status as variables. Previous assessments of government strength assume that single-party majority governments are 'stronger' than 
coalitions (e.g. Roubini and Sachs 1989; Bohrer 2001). As Bohrer put it, 'a single party majority government has no partners to consider or consult, and hence has greater autonomy than partners in a coalition setting.' We formulated the hypotheses as follows:

Hypothesis 2a: All governments will amend legislation

Hypothesis 2b: A weaker government will produce more-amended legislation.

Hypotheses $2 \mathrm{a}$ and $2 \mathrm{~b}$ were tested by comparing the amount of amendment in three parliamentary sessions (2008-09, 2012-13, and 2015-16). In 2008-09, the Labour government had a majority of 66 seats, in 2012-13 the Conservative-Liberal-Democrat coalition had a 76-seat majority, and in 2015-16 the Conservatives had a narrow majority of about twelve seats. This set of three parliamentary sessions does not of course allow us to disentangle all of the possible effects of party and majority, as the government majority did not vary independently of the party in power, and neither did we determine the policy position taken in each bill. Furthermore the relatively small sample allowed only a few explanatory variables to be included. Two important factors could be the policy area and the complexity of the bill. In order to control for policy area, each bill was coded as dealing with public services, financial and business issues, or constitutional and citizenship issues. As a proxy for complexity, the duration of the parliamentary process was recorded, as well as the length of the bill, and whether it was carried over to the next session.

\subsection{Methodological rationale}

Although there are several quantitative studies of amendments described and cited above, we found it surprising that so few scholars have applied computerised text-comparison methods. Among the cited studies, as far as we can ascertain only Pedrazzani and Zucchini (2013) used automated methods. In other fields, such as bioinformatics or software version control, techniques for comparing 'code' (whether genetic code or lines of software) are well established. Since DNA sequencing was developed in the 1970s (Sanger et al. 1977) the field of bioinformatics has analysed evolutionary relationships and the mutation of genes (e.g. Emms and Kelly 2015; van't Hof et al. 2016). Genetic maps provide an intuitive way of visualizing genetic differences between species, individuals, and genes, and the degree of similarity or dissimilarity of genes from different organisms can readily be calculated (Agostino 2013). Legislative changes can be likened to the mutations in DNA, which involves additions or deletions of sections of code, and single word (or letter) changes, and the degree of dissimilarity represents the amount of amendment. Accordingly, we developed a method inspired by bioinformatics to visualize and quantify the amendments agreed in successive parliamentary stages during the passage of a piece of legislation. 
Our analysis required us to decide on the appropriate unit of comparison. Genetic code is compared on a letter-by-letter basis, while software version control is line-by-line (see e.g. Kemper and Oxley 2012). Pedrazzani and Zucchini (2013) cited above, used word frequency comparisons of Italian laws, and in an example from a related field, Baerg and Hallerberg (2016) used word-by-word comparison in a study of changes to EU Commission country assessments. While our method compares the text on a letter-by-letter basis, we report the degree of alteration as the proportion of lines changed. We believe that the line of legislative text is most suited to the cognitive process of legislative scrutiny. That is, when a legislator reads the text of a bill, they scrutinise the printed line (or few lines) of text rather than the individual word or letter. This is similar to Martin and Vanberg's (apparently manual) comparison of legislative subsections which they consider to be the smallest 'logically separate units' (Martin and Vanberg 2011:77). Our choice of 'lines' rather than 'subsections' allows us to automate the comparison process without requiring a script that can recognize 'a subsection,' which is especially valuable in the case of non-standard portions of text such as tables. Our method offers several advantages over previous analyses. As the size and position of each change is automatically recorded, the distribution of amendments throughout the bill can readily be visualised and analysed. This allows us to identify the positions of particularly 'unstable' sections of text. We also capture both versions of the altered lines in a text file, which can be used for further qualitative and quantitative analysis.

The rest of this paper describes our method and presents the results of our exploratory analyses. Finally, we discuss the implications of our results and describe future directions for this research.

\section{Methodology and data sources}

\subsection{A semi-automated approach to mapping and quantifying amendments}

Our method comprised the following three 'semi-automated' steps. First, a Python (version 2.7, Python Software Foundation, python.org) script was used to strip extraneous material from the electronic text of bill versions to create 'simplified' text files containing only the legislative text (omitting e.g. page and table headers, page and line numbers, front- and end-matter, as well as other numbers and most punctuation). Second, free software ${ }^{1}$ was used to compare pairs of simplified bill versions and to generate a 'patch file' of differences. Third, the patch file was analysed by another Python script to produce the data-visualisation and quantitative summary. Dissimilarity between two versions was calculated by analogy with genetic dissimilarity (Agostino 2013) as the percentage of lines changed: (lines deleted + lines added)/(lines deleted + lines added + lines unchanged $) \times 100$ per cent. A change of

\footnotetext{
${ }^{1}$ Various comparison programmes are available: we used 'WinMerge' (WinMerge 2.14.0, winmerge.org).
} 
letter(s) or word(s) within a line was recorded as the deletion of the original line and addition of a new line.

\subsection{Data sources}

Published versions of government bills were downloaded as native PDFs ${ }^{2}$ from the parliamentary website (http://www.parliament.uk/). Up to six versions of each bill are published, each showing the version amended at a parliamentary stage that allows amendment. If no amendments are made at a particular stage, new versions are only published when the bill enters the next chamber and when the final Act of Parliament is agreed.

\subsection{Validation exercise: classification of detected differences}

Seventy-two bill version comparisons were analysed manually to determine whether each detected difference was due to a parliamentary amendment, or arose for other reasons. Certain types of change can occur between bill versions which do not require parliamentary amendments but are detected by our method alongside actual amendments. These include typographical corrections, alterations to section titles, and renumbering or lettering of subsections consequent to earlier amendments (Cabinet Office 2017:172). In addition, for text extracted from PDFs, differences occur if words within a paragraph break differently across lines, and if tables split differently across pages.

For these comparisons, each detected change was manually classified as being either the result of (one or more) parliamentary amendments or a 'formatting' or other typographical change. Where the classification was uncertain it was checked by reference to the online record of agreed amendments. Comparing 'all' and 'amendment-only' changes allowed the calculation of the amount of change for 'other' (non-amendment) reasons.

\subsection{Exploratory studies}

Hypotheses $1 \mathrm{a}$ and $1 \mathrm{~b}$ were tested using the 17 bills in which each difference had been classified for the validation exercise. Each parliamentary stage in which the bill might be amended was analysed (a total of 85 comparisons). No new bill version is published when no amendments are agreed at a particular stage (unless the bill is due to enter the next chamber), and the change in those 13 cases was recorded as zero. Only changes coded as being due to amendments were analysed. Hypothesis 1 a was tested by comparing the

\footnotetext{
2 'Native' PDFs are created from electronic sources, rather than by scanning paper copies. Such files are available since about 2007 for UK bill versions. Since about 2015, XML files are also available for some bill versions, which can be analysed in a similar way, and have certain advantages over the PDF format for our method.
} 
proportion of text changed in committee and report stages in the Lords and Commons by paired t-tests. Hypothesis $1 \mathrm{~b}$ was tested by comparing the Lords third reading stage with all other stages by an unpaired t-test.

Hypothesis 2 was tested by comparing the initial and final versions of all government bills from three parliamentary sessions (2008-09, 2012-13, and 2015-16), excluding bills containing fewer than 200 lines of legislative text and Finance and Appropriation Bills (which are subject to different patterns of amendment). Thus a total of 56 bills was analysed. All detected changes were included (as discussed above, this slightly overestimates the percentage of lines altered by parliamentary amendments). Ordinary least squares (OLS) regression was used to test the relationship between the dependent variable (percentage of lines altered) and the explanatory variables. The dependent variable was normally distributed according to the Shapiro-Wilk test. Explanatory variables included the size of the government majority, whether or not it was a coalition, the general policy area of the bill (public services, financial and business issues, constitutional and citizenship issues), the initial length of the bill (lines of legislative text), the House in which it was introduced, the duration of the parliamentary process (days from first reading to Royal Assent), and whether the bill was carried over to the next session.

\section{Results}

\subsection{Method feasibility}

Our methodology conveniently produces a quantitative measure of textual changes and a novel visual display of amendments at each stage of the parliamentary process for UK legislation. Figure 1, for example, shows the amendments made at each parliamentary stage of the Crime and Courts Bill 2013. The figure illustrates the utility of the method, clearly showing the variation in the number of amendments made in different parliamentary stages, and demonstrating the increasing length of the bill during the parliamentary process. Amendments can be seen to occur throughout the bill, with some portions of the text particularly amended. 
Figure 1. Amendments of the Crimes and Courts Act 2013 at each parliamentary stage. Key: additions: blue; substitutions: black; deletions: red.
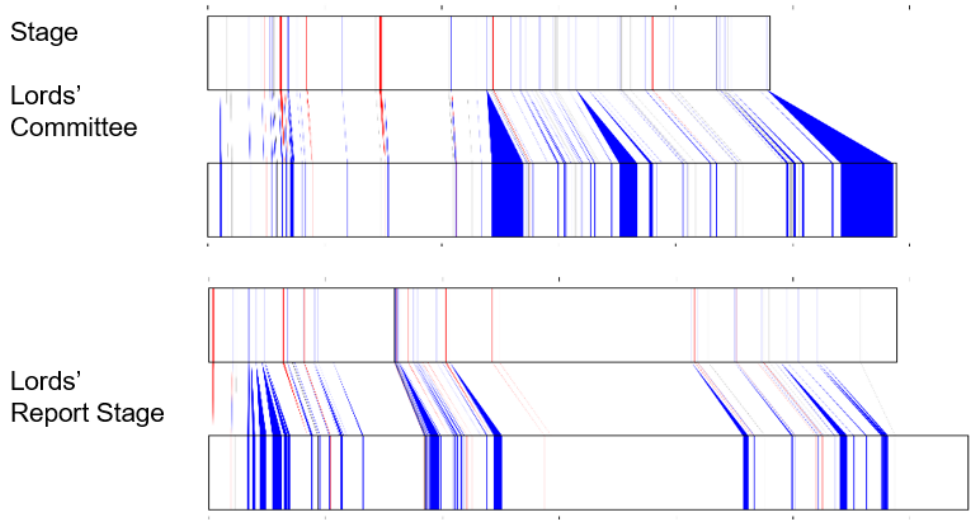

Lords' Third Reading

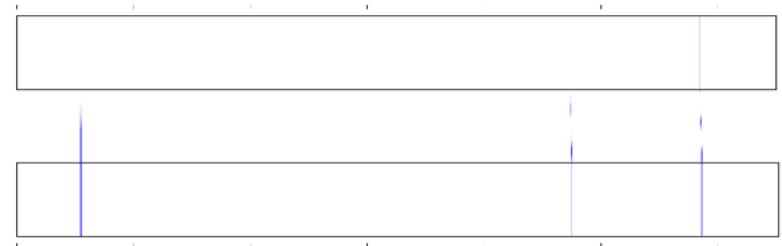

Commons' Public Bill

Committee
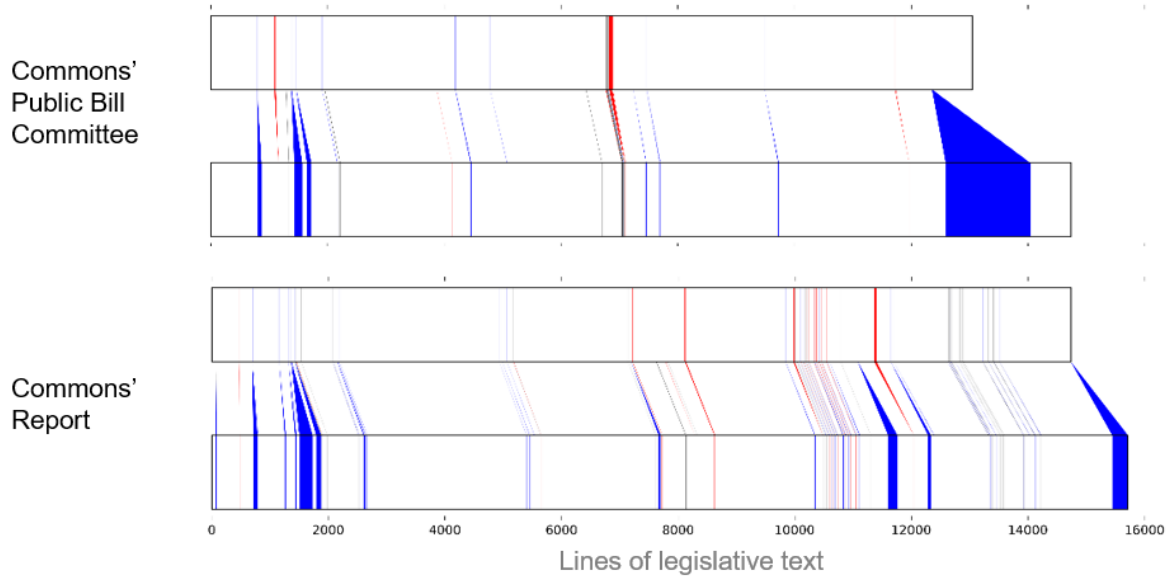

\subsection{Validation exercise: classification of changes}

In order to determine how well our automated method excluded irrelevant changes we manually classified each detected change in 72 bill version comparisons. The results of that exercise are shown in Figure 2, which shows that the percentage of text altered by 'nonamendment' changes was low and relatively constant, ranging from 0 to 6.0 (median 1.3 per cent), while the percentage altered by amendments in each stage varied from 0 to 41.5 
(median 5.9 per cent). Thus, omitting the time-consuming manual classification step would only slightly overestimate the degree of amendment.

Figure 2. Percentage of text changed in 72 bill stage comparisons (ordered by overall level of change).

50

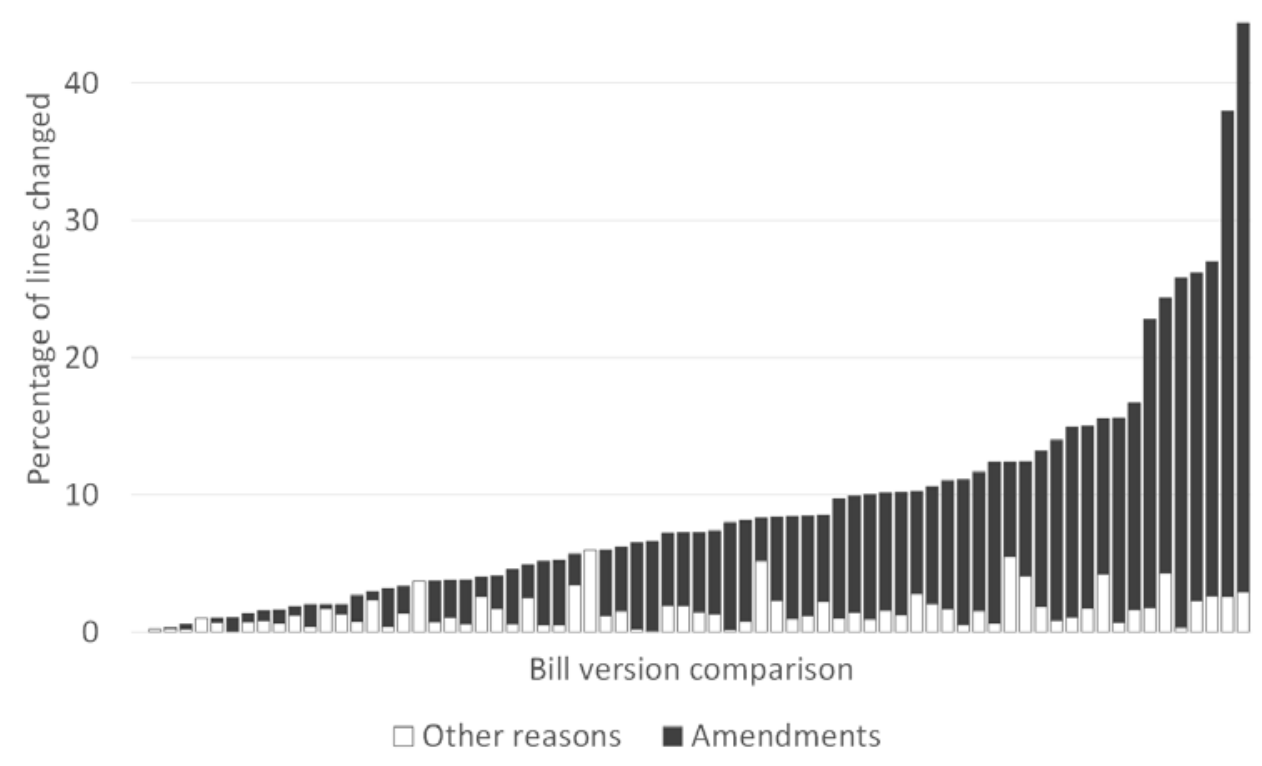

\subsection{Comparison of bill stages}

In this exploratory evaluation we compared successive pairs of bill versions at each parliamentary stage for 17 government bills published between 2009 and 2013. In individual parliamentary stages, up to forty per cent of the text of each bill in the sample was altered (the average proportion across all 85 stages was 6.3 per cent). The level of amendment differed somewhat between stages, but Hypothesis 1a was not supported, in that we found no significant differences between the proportion of text changed in committee and report stages, either in the Commons or the Lords. Hypothesis $1 \mathrm{~b}$ was supported, however, in that the least amount of text changed at the Lords Third Reading stage. ${ }^{3}$

\subsection{Three parliamentary sessions compared}

To test Hypotheses $2 a$ and $2 b$, we compared the first with the final version of 56 government bills in three recent parliamentary sessions under different governments: 2008-

\footnotetext{
${ }^{3} p=0.002$ for a t-test comparison between the Lords Third Reading stage (mean 2.6 per cent of lines altered) and all other stages (mean 7.2 per cent).
} 
09 (Labour, majority 66 seats), 2012-13 (Conservative-Liberal-Democrat coalition, majority 76), and 2015-16 (Conservative, majority 12). It should be noted that the comparison of initial with final versions disregards any amendments that were made in intermediate stages but subsequently overturned. As Figure 3 demonstrates, this sample of bills was subject to considerable amendment. On average, about a third of the lines in each bill were altered during the entire parliamentary process, thus supporting Hypothesis 2a (that all governments amend legislation). There was a wide variation between bills, with a few bills passing without amendment, but in 18 per cent of bills more than half of the lines of text were altered. Legislation grew considerably in length during the parliamentary process, averaging over forty per cent increase. Very short bills (less than 200 lines of legislative text) were analysed separately and were found to be less amended than longer bills, with 14 out of the 16 very short bills in these parliamentary sessions receiving no amendments at all. Above that threshold there was no relationship between the length of the bill and the proportion of text changed.

Figure 3. Overall percentage of text changed in $\mathbf{5 6}$ government bills from three parliamentary sessions.

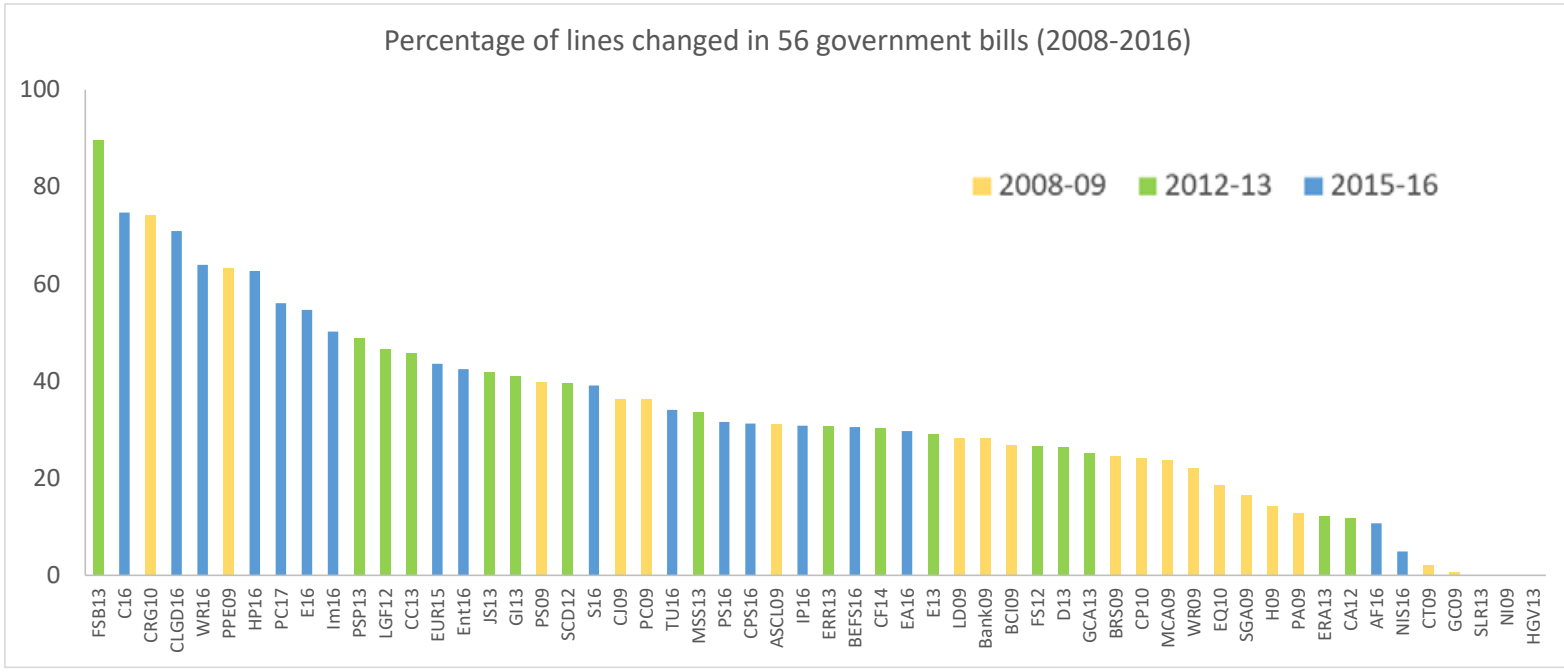

The three sessions differed in their amount of amendment, as illustrated in Figure 3. An average of 20 per cent of lines were altered during the Labour session of 2008-09, with only two bills having more than 40 per cent alteration. 32 per cent of lines were altered during the Coalition session of 2012-13, and 42 per cent during the Conservative session of 201516. The 2015-16 session contained seven of the ten most-amended bills. The results of the regression analysis are shown in Table 1 . Hypothesis $2 \mathrm{~b}$ was supported: that is, the weakest government produced the most-amended legislation, and the government majority was a significantly negatively correlated with the amount of amendment (Model 1). A coalition government is expected to be weaker than a one-party majority (Bohrer 2001). Hence, including the coalition status as a variable gave a coefficient of the expected sign (though 
not in itself statistically significant) and slightly improved the fit (Model 2). Including the duration of the bill and whether it was carried over to the next session improved the fit further (Model 3). Other explanatory variables (policy topic, length of bill, and chamber where the bill was introduced) did not improve the model fit or alter the significance of the coefficients.

\section{Table 1 about here}

\section{Discussion}

This paper describes our novel semi-automated method for quantifying and visualizing legislative amendment. The validation exercise described above, in which each detected change was classified as being caused either by parliamentary amendment or for other reasons such as typographical corrections, demonstrated that the level of 'other' changes was relatively low and consistent across bill version comparisons. The great majority of alterations were attributable to parliamentary amendments. Hence this method provides a reliable measure of the amount of amendment.

We demonstrated the utility of the method in two ways. First, we explored the degree of amendment at each parliamentary stage in the UK legislative process. We found that, as expected, the Lords third reading stage demonstrated least amendment, but we did not find any difference between report and committee stages in the Commons or the Lords. The results of this exploratory study should be interpreted with caution due to the limited number of bills, but the analysis demonstrates that meaningful comparisons can be made by semi-automated methods without any need to manually count or classify amendments. As with any similar text-comparison method, analysing each stage of a bill in this way will detect all amendments made at that stage even if they were later reversed. It would be possible to analyse the patch files for such reversals, or alternatively one could compare the initial with the final versions of bills which will ignore any reversals altogether (as we did in the second exploratory study described below).

In the second part of our exploratory study, we compared the first and final versions of bills from three parliamentary sessions under different governments (Labour, ConservativeLiberal-Democrat Coalition, and Conservative). Almost all bills of over 200 lines in length were amended to some extent with, on average, over thirty per cent of the lines of text altered and over forty per cent added to the lengths of the bills. Legislation was considerably amended under all three governments. Insofar as all amendments are evidence of some failure of communication, prediction, or understanding on the part of the 
government, this high level of amendment supports the hypothesis that bounded rationality affects the legislative process.

The shortest bills (under 200 lines of legislative text) tended to be less amended, with the majority of the sample (14 out of 16) passing without amendment. This could reflect better preparation of very short bills, which typically address only one policy issue. Nevertheless, above this threshold we found no relationship between bill length and proportion of lines amended, showing that longer bills are not necessarily any less well prepared than mediumsized bills.

The degree of amendment differed between parliamentary sessions. In particular, the government with the smallest majority (the 2015-16 session of David Cameron's Conservative government) showed the greatest alteration of bills, followed by the 2012-13 session under the Coalition. These results support the hypothesis that weaker governments produce more-amended legislation particularly if, as has been suggested, coalition governments are intrinsically weaker than one-party majorities (Bohrer 2001). As noted above, these results are only indicative since the effects of party and other session-specific factors cannot be disentangled from the other variables considered in the analysis. Notably, the UK very rarely produces coalition governments and so there are no other recent UK examples with which to compare the government 'strength' of the 2010-2015 coalition.

The average amount of amendment found in this study is consistent with the two other studies that allow an approximate comparison. Pedrazzani and Zucchini (2013, Appendix 8) analysed the alterations to 646 Italian bills from 1987 to 2006, and found that (for various values of the independent variables) the predicted number of alterations was between 200 and 500 words for a simulated bill of length 771 words, representing changes to 25 to 65 per cent of the text. In their study of 1300 bills from five European legislatures (not including the UK) Martin and Vanberg (2011:78) found that an average of 30 to 35 per cent of legislative sub-articles were amended. They found that more than half of the sub-articles were amended in about a quarter of bills, which is comparable with our finding of more than half of lines amended in 18 per cent of bills. Despite the differences in methodology, units of comparison, and sample, it is apparent that our method finds that UK legislation is amended to a similar extent as legislation from other legislatures.

Returning to our question, 'why do governments amend legislation?' we are still faced with a conundrum. Each of the governments in our study had a working majority. They did not have to bow to opposition pressure to introduce amendments, and yet many amendments were made. But this argument assumes that the only pressure comes from other parties, 
and that the government can always count on its own backbench vote. In fact backbenchers in the UK have become increasingly likely to vote against their party in recent decades (Cowley and Stuart 2014a; Russell and Cowley 2016). Of course, 'rebel votes' are not the only way that backbenchers can exert pressure, but it is an objective measure of backbench opinion and may reflect pressure applied in other, less measurable, ways. The 'anticipated reactions' of the backbenchers is believed to be a significant influence on the policies put forward by ministers (Russell and Gover 2017: 118; Russell et al. 2016). Insofar as ministers misjudge those reactions, concessions may be required. For example, Cowley and Stuart (2014a: 9) describe how Labour dissent about aspects of the Counter-Terrorism Bill in the 2007-08 session, while not leading to government defeats, meant that policy concessions were made by the Home Secretary in order for the bill to gain enough support from government backbenchers.

In the first two parliamentary sessions analysed in this paper, votes against the party line occurred at historically high (though not record) levels, with the 2008-09 session showing rebellions by government MPs in 30 per cent of Commons divisions (Cowley and Stuart 2014a:7) and in the 2012-13 coalition parliament in 27 per cent of divisions (Cowley and Stuart 2013; 2014b). No precisely comparable numbers are available for the 2015-16 session, but data from The Public Whip (http://www.publicwhip.org.uk) suggest that just under 22 per cent of Commons divisions included one or more rebel government MPs, suggesting that party discipline was stronger in that session, perhaps because the government majority was so much smaller. Most of the votes were not on legislation or amendments, and few led to government defeats, but the effect of the 'rebelliousness' of government backbenchers on the level of amendment is a promising topic for further investigation.

These results raise the practical question, what effect do these sometimes numerous amendments have on the quality of the resulting legislation? Do amendments matter? While amendment is intended to improve legislation, there are at least two reasons why excessive levels of amendment could have the opposite effect.

First, highly amended legislation may reflect inadequate preparation. A House of Lords report noted in 1987: 'Government legislation has been more heavily amended in the Lords than in previous Sessions [...] which suggests than legislation may have been introduced without adequate consideration' (House of Lords 1987). And former government adviser Christopher Foster argued in 2005 that legislation was increasingly poorly prepared and required numerous amendments to 'repair' it during the parliamentary process (Foster $2005: 134)$. One might expect that such 'patched-up' legislation might not achieve the quality of legislation which enters parliament in a better-prepared form, despite the drafting 
expertise of Parliamentary Counsel and the technical advances that make the insertion of amendments more practicable.

Second, amendments will always receive less parliamentary scrutiny than the originally drafted legislation. Amendments avoid the formal processes of pre-legislative scrutiny and consultations altogether, and often receive rather little scrutiny in parliament. Former Parliamentary Counsel Daniel Greenberg argued that due to shortage of time, legislation does not always receive the detailed parliamentary scrutiny that it deserves (Greenberg 2016) and government amendments are often agreed en masse with little or no discussion.

This is not popular with legislators. For example, as shown in Figure 4, the Financial Services (Banking Reform) bill was hugely amended in 2013 during the Lords committee stage after the publication of the final report of the Parliamentary Commission on Banking Standards (Korotana 2016). This action on the part of the government was roundly criticised by legislators in both chambers as bypassing or curtailing much of the usual processes of scrutiny and consultation:

Lord Turnbull: "... there are important provisions here that need to go to various committees which we have set up in this House to examine such things."

(Hansard, 23 Oct 2013 : Column 1170, Lords Committee Stage)

Cathy Jamieson MP: “...this House had to consider the partial Bill before the final report on standards and culture had been published. [...] I wish to put on record our concerns about that method of legislation. The Bill is now three times bigger than the one that was originally introduced, and consideration of Lords amendments took place only a couple of days after Third Reading-again, without much opportunity to consider matters in detail."

Gordon Marsden MP: "Does she agree that if we had had longer, organisations and groups outside the House, which feel very strongly on these issues, would have had more opportunity to make representations? The Government's failure to allow that, by tabling these amendments as they have done, has circumscribed the public process."

(Hansard, 11 Dec 2013 : Column 254, Commons consideration of Lords amendments) 
Figure 4. Amendments to the Financial Services (Banking Reform) Act 2013 at each parliamentary stage. Key: additions: blue; substitutions: black; deletions: red.

Financial Services (Banking Reform) Act 2013
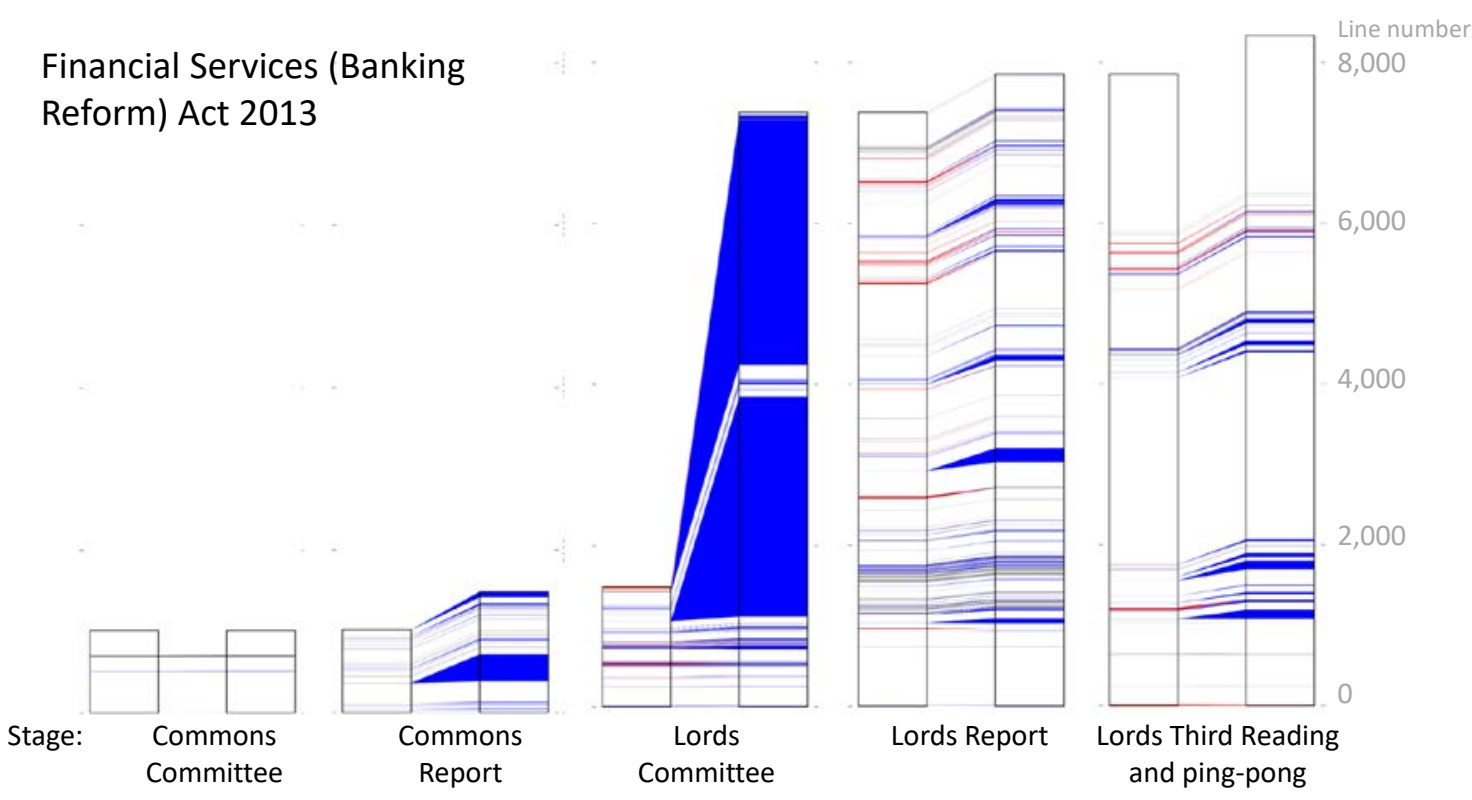

Given the concerns voiced about this (admittedly extreme) example, we believe that the link between high levels of amendment and lower quality of legislation is worthy of further investigation. The quality of legislation might be operationalised by analysing evaluations such as post-legislative scrutiny, post-enactment reviews, or judicial challenges.

\section{Conclusion}

By providing an effective way of measuring and visualizing the level of amendment of legislation, our methodology can contribute to studies of the quality of legislation and the politics of the legislative process. Our exploratory study revealed high levels of amendment across all three parliamentary sessions under different governments. The government with the smallest majority was least able to resist amendments, but governments with much larger majorities also produced highly amended legislation. This supports our thesis that bounded rationality is an underlying cause of legislative amendment.

Our method has certain limitations. In particular, we do not attempt to classify the substantive effect of amendments, as some scholars do (e.g. Kreppel 1999, Shephard and Cairney 2005, Thompson 2015, Russell and Gover 2017) and our method does not detect amendments that were proposed but not agreed. Instead, like Martin and Vanberg (2011) and Pedrazzani and Zucchini (2013), we take the approach that the aggregate amount of alteration is a satisfactory proxy for the degree of legislative change. Coding the legal effect of each amendment requires detailed expertise and knowledge of the policy area as well as 
being extremely labour-intensive and inherently subjective. Nevertheless, for studies of the substance, types, or origins of amendments, our method automatically generates a file of the lines of altered text which can be coded or subjected to further linguistic and mathematical analysis (e.g. Williams 2016; Bommarito and Katz 2010).

Our method has the distinct advantage of being generally applicable across a wide range of legislation and legislatures wherever suitable electronic versions of bill texts are available. Our study of UK legislation was limited by the lack of suitable electronic bill versions from before 2007, but the availability of recent legislation in formats such as XML suggests that studies of this type will become much more practicable and widespread in the future. 
Table 1. OLS regression of the degree of amendment in $\mathbf{5 6}$ government bills (the dependent variable is the percentage of lines altered).

\begin{tabular}{|c|c|c|c|}
\hline & Model 1 & Model 2 & Model 3 \\
\hline & \multicolumn{3}{|c|}{ Coefficient (SE) } \\
\hline Government Majority (seats) & $-0.21(0.09)^{*}$ & $-0.30(0.12) *$ & $-0.31(0.11) * *$ \\
\hline Coalition (=1, otherwise 0$)$ & - & $8.97(6.95)$ & $6.78(6.76)$ \\
\hline Duration (days) & - & - & $0.04(0.03)$ \\
\hline Carried-over $(=1$, otherwise 0$)$ & - & - & $9.57(6.38)$ \\
\hline Adjusted $\mathrm{R}^{2}$ & 0.066 & 0.078 & 0.142 \\
\hline $\mathrm{N}$ & 56 & 56 & 56 \\
\hline
\end{tabular}




\section{References}

Agostino, M. (2013) Practical Bioinformatics, New York, Garland Science.

Baerg, N.R. and Hallerberg, M. (2016) 'Explaining Instability in the Stability and Growth Pact: The Contribution of Member State Power and Euroskepticism to the Euro Crisis' Comparative Political Studies, 49, 968-1009.

Bohrer, R.A. (2001) Revival: Decision Costs and Democracy: Trade-offs in Institutional Design, London, Routledge

Bommarito II, M. J. and Katz D. M. (2010) 'A Mathematical Approach to the Study of the United States Code', Physica A, 389, 4195-4200.

Cabinet Office (2017) Guide to Making Legislation, London, Cabinet Office.

Constitution Committee (2004) Parliament and the Legislative Process, 14th Report of Session 2003-04, HL Paper 173.

Constitution Committee (2011) Money Bills and Commons Financial Privileges, 10th Report of Session 2010-11, HL Paper 97.

Cowley, P. and Stuart, M. (2013) 'Cambo Chained', accessed at nottspolitics.org/2013/05/14 on 13 January 2018.

Cowley, P. and Stuart, M. (2014a) 'In the Brown Stuff? Labour Backbench Dissent Under Gordon Brown, 2007-10,' Contemporary British History, 28, 1-23.

Cowley, P. and Stuart, M. (2014b) 'Rates of rebellion, 1945-2014', accessed at revolts.co.uk/?p=711 on 13 January 2018.

Drewry, G. and Brock, J. (1993) 'Government Legislation: An Overview' in The House of Lords at Work, A Study Based on the 1988-1989 Session, eds. Donald Shell and David Beamish, Oxford, Clarendon Press.

Emms, D. M. and Kelly, S. (2015) 'OrthoFinder: solving fundamental biases in whole genome comparisons dramatically improves orthogroup inference accuracy', Genome Biology, 16, 157.

Flinders, M. and Kelso. A. (2011) 'Mind the Gap: Political Analysis, Public Expectations and the Parliamentary Decline Thesis.' British Journal of Politics and International Relations, 13, 249-268.

Foster, C. (2005) British Government in Crisis, Oxford, Hart Publishing.

Gallagher, M., Laver, M. and Mair, P (2011) Representative Government in Modern Europe (5th edition). New York: McGraw-Hill.

Greenberg, D. (2016) Dangerous Trends in Modern Legislation... and How To Reverse Them, London, Centre for Policy Studies.

Griffith, J.A.G. (1974) Parliamentary Scrutiny of Government Bills, London, Allen and Unwin. 
Hood, C. and Dixon, R. (2015) A Government that Worked Better and Cost Less? Evaluating Three Decades of Reform and Change in UK Central Government, Oxford, Oxford University Press.

House of Lords (1987) Report on the Working of the House, HL Paper 9.

House of Lords (2011) Bills and How They Become Law: Stages of legislation and types of bills, London, House of Lords.

Kemper, C. and Oxley, I. (2012) Foundation Version Control for Web Developers, New York, Apress.

Korotana, M.S (2016) 'The Financial Services (Banking Reform) Act 2013: Smart Regulatory Regime?' Statute Law Review, 37, 195-211.

Krehbiel, K. (1991). Information and legis/ative organization. Ann Arbor, MI: University of Michigan Press.

Kreppel, A. (1999) 'What Affects the European Parliament's Legislative Influence? An Analysis of the Success of EP Amendments', Journal of Common Market Studies, 37, 521-538.

Levy, J. (2010) 'Public Bill Committees: An Assessment-Scrutiny Sought; Scrutiny Gained', Parliamentary Affairs, 63, 534-44.

Martin, L. W. and Vanberg, G. (2005) 'Coalition Policymaking and Legislative Review', American Political Science Review, 99, 93-106.

Martin, L.W. and Vanberg, G. (2011) Parliaments and Coalitions: The Role of Legislative Institutions in Multiparty Governance, Oxford, Oxford University Press.

Martin, L.W. and Vanberg, G. (2014) 'Parties and Policymaking in Multiparty Governments: The Legislative Median, Ministerial Autonomy, and the Coalition Compromise', American Journal of Political Science, 58, 979-996

Mezey, M. (1979) Comparative Legislatures, Durham, NC, Duke University Press.

Norton, P. (1993) Does Parliament Matter? New York, Harvester Wheatsheaf.

Page, E.C. (2003) 'The Civil Servant as Legislator: Law Making in British Administration', Public Administration, 81, 651-679.

Page, E.C. (2009) 'Their Word is Law: Parliamentary Counsel and Creative Policy Analysis', Public Law, 2009, 790-811.

Pedrazzani, A. and Zucchini, F. (2013) 'Horses and hippos: Why Italian government bills change in the legislative arena, 1987-2006,' European Journal of Political Research, 52, 687-714.

Roubini, N. and Sachs, J. (1989) Government spending and budget deficits in the industrial countries, Economic Policy, 4, 99-132. 
Russell, M. and Cowley, P. (2016) 'The Policy Power of the Westminster Parliament: The "Parliamentary State" and the Empirical Evidence,' Governance, 29, 121-137.

Russell, M., Gover, D. and Wollter, K. (2016) 'Does the Executive Dominate the Westminster Legislative Process? Six Reasons for Doubt', Parliamentary Affairs, 69, 286-308.

Russell, M. and Gover, D. (2017) Legislation at Westminster: Parliamentary Actors and Influence in the Making of British Law, Oxford, Oxford University Press.

Sanger, F., Nicklen, S. and Coulson, A. R. (1977) DNA sequencing with chain-terminating inhibitors, Proceedings of the National Academy of Sciences, USA, 74, 5463-7.

Shephard, M. and Cairney, P (2005) 'The Impact of the Scottish Parliament in Amending Executive Legislation,' Political Studies, 53, 303-319

Simon, H.A. (1957) Models of Man, New York, Wiley \& Sons.

Smookler, J. (2006) 'Making a Difference? The Effectiveness of Pre-Legislative Scrutiny,' Parliamentary Affairs, 59, 522-535.

Thompson, L. (2015) Making British Law: Committees in Action. Basingstoke, Palgrave Macmillan.

Thompson, L. (2016) 'Debunking the Myths of Bill Committees in the British House of Commons,' Politics, 36, 36-48.

Tolley, M.C. (2009) 'Parliamentary Scrutiny of Rights in the United Kingdom: Assessing the Work of the Joint Committee on Human Rights,' Australian Journal of Political Science, 44, 41-55.

Tsebelis, G., Jensen, C. B., Kalandrakis, A. and Kreppel. A. (2001) 'Legislative Procedures in the European Union: An Empirical Analysis', British Journal of Political Science, 31, 573 599.

van't Hof, Arjen E., Campagne, P., Rigden, D.J., Yung, C.J., Lingley,J., Quail, M.A., Hall, N., Darby, A.C. and Saccheri, I.J. (2016) 'The industrial melanism mutation in British peppered moths is a transposable element', Nature, 534, 102-105.

Williams, M. (2016) 'Indeterminate Sovereignty and the Rule of Law: A Descriptive Analysis of Changes to Parliament's Use of Language', British Politics, 11, 26-48. 